\title{
DETERMINING THE TEMPORAL CHANGES IN AVIAN POPULATION INHABITING URBAN SEASONALLY WATERLOGGED AREAS IN HYDERABAD SINDH, PAKISTAN
}

\author{
RAJPAR, M. N. ${ }^{1}$ - HASSAN-ABOUSHIBA, A. B. ${ }^{2}$-ULLAH, S. ${ }^{1}$-OZDEMIR, I. ${ }^{3}$-UlLAH, A. ${ }^{4}$-ZAKARIA, M. ${ }^{5 *}$ \\ ${ }^{I}$ Department of Forestry, Faculty of Life Sciences, Shaheed Benazir Bhutto University \\ Sheringal, Dir (Upper), Khyber Pakhtunkhwa 18051, Pakistan \\ (e-mail: rajparnawaz@gmail.com,sami.ullah@sbbu.edu.pk) \\ ${ }^{2}$ Department of Zoology, Faculty of Science, University of Sebha, Libya \\ (e-mail: abushibaa@yahoo.com) \\ ${ }^{3}$ Department of Wildlife Ecology and Management, Faculty of Forestry \\ Isparta University of Applied Science, 32260 Cunur, Isparta, Turkey \\ (e-mail:ibrahimozdemir@isparta.edu.tr)
}
${ }^{4}$ Department of Agricultural Extension Education and Communication, The University of Agriculture Peshawar, Pakistan
(e-mail: ayat.ullah@zalf.de)

${ }^{5}$ Faculty of Forestry, Universiti Putra Malaysia, 43400 UPM Serdang, Selangor, Malaysia (e-mail: mzakaria@upm.edu.my)

${ }^{*}$ Corresponding author

e-mail: mzakaria@upm.edu.my

(Received $14^{\text {th }}$ Mar 2019; accepted 21 $1^{\text {st }}$ May 2019)

\begin{abstract}
Determining the temporal change in avian population is crucially important in order to understand whether their population is increasing or decreasing. The information about population parameters will help in conservation and protection efforts of avian species in future. Hence, the present study was carried out to determine the temporal changes in avian species in the 2014/15 and 2018/19 periods in urban waterlogged area of Hyderabad district Sindh, Pakistan. The highest relative abundance (28229 bird individuals representing 50 species and 14 families) was detected in 2018/19 rather than in 2014/15 (17454 individuals representing 38 bird species and 12 families). Out of the 50 bird species detected in 2018/2019, 30 were migrants (18965 individuals); 15 residents (5370 individuals), and 5 resident-migrants (3897 individuals) and while in the case of 2014/15 period, 22 species were migrants (11547 individuals), 15 residents (5247 individuals) and one resident-migrant (660 individuals). IUCN and BirdLife Status indicated that one migrant species was critically endangered; two species Rare/Accidental/Vulnerable and the rest of the 23 species were of the least concern. All resident bird species were totally protected (LC) while one resident-migrant species was data deficient. Foraging guild structure indicated that omnivore (32.489\%) and Piscivore (12.808\%) were the most dominant guilds of 2018/19 rather than 2014/15 while Carnivore was absent in detections of 2014/15. Alpha diversity analysis indicated that urban seasonal waterlogged was more diverse, rich and evenly distributed in 2018/19 than 2014/15. The findings of this study indicated that urban seasonal waterlogged area is suitable habitat (foraging sites and stopover) for a wide array of waterbird species especially migrant birds to refuel, rest, and forage.
\end{abstract}

Keywords: waterbirds, population parameters, native, threatened, BirdLife

\section{Introduction}

Waterbirds are directly or indirectly depend on the aquatic environment and foraged either near water body's edges or banks or on the surface. They are bioindicators of aquatic ecosystems due to cause-effect association with different microclimate and 
vegetation composition. Waterbirds may exploit broad scale of habitat, responded quickly to any environmental change either microclimate or vegetation structure and composition. Waterbird can be easily detected and identified (i.e., they showed their presence through vocalization). They can be surveyed more efficiently over the large spatial scale, e.g., presence, abundance, and influenced by surrounded habitats as compared to other animals.

The urban seasonal waterlogged areas are the undeveloped residential low-lying landscape within the city that received the water from domestic sewage and rainfall drain. They are characterized with shallow water overlying the interspersed soil and dominated either by submerged and emergent aquatic vegetation (Zhang et al., 2010). Waterlogged areas have been considered highly productive habitats for diverse fauna species, such as birds, amphibians, reptiles and mammals (Ehrenfed, 2000; Gibbs et al., 2005; Van der Walk, 2006). Due to loss and degradation of natural wetland areas, urban sewage has become a hotspot habitat for a wide array of waterbird species, i.e., waterfowls, waders, grebes, gulls, cormorants, terns to refuel, rest, and forage. These areas provide an important stopover foraging habitat for migrant as well as resident waterbird species due to high productivity (Hoffmann and Dodson, 2005). The other reason could be that, these areas are rich in fishes, amphibians, aquatic invertebrates (i.e. snails, worms, larvae of dragonflies, and water beetles that mostly occurs in soft damp soils, ditches, ponds), and organic matter.

It has been stated that more than $50 \%$ of the world's population inhabit in cities (Mackintosh and Davis, 2013) that may cause huge domestic sewage. A rapid increased in urbanization i.e., draining and infilling of wetland for development may also have caused the disappearing of wetlands from landscape (Sutula and Stein, 2003). The loss and degradation of wetland areas have increased runoff from urban sewage and industrial plants, which has adversely affected the hydrology of waterways and the remaining rest of wetlands (Catford et al., 2007; Vermoden et al., 2009; Davis et al., 2010). It has also been reported that more $50 \%$ of natural wetlands had been lost and degraded (Fraser and Keddy, 2005) that caused almost $40 \%$ of migrant bird species (i.e., 200 bird species) to be declined worldwide (BirdLife, 2015).

Previously, no study has been conducted to examine the temporal changes in avian population parameters inhabiting urban seasonal waterlogged areas. Hence, this study was conducted to examine the temporal changes in the avian population (i.e., relative abundance, diversity, status, and foraging guild structure) that utilizing the urban seasonal waterlogged areas.

\section{Materials and methods}

\section{Study Area}

These urban seasonal waterlogged areas lie in within the heart of the city $25^{\circ} 22^{\prime} 45^{\prime \prime}$ $\mathrm{N}$ and $68^{\circ} 22^{\prime} 06^{\prime \prime} \mathrm{E}$ along the east bank of the Indus River, Hyderabad Sindh, Pakistan (Figure 1). Hyderabad city is densely populated, i.e., 2.323 million urban inhabitants and covers a total area of $3,198 \mathrm{~km}^{2}$. It received monsoon rainfall from mid-April to late June and mostly remains warm (i.e., $50^{\circ} \mathrm{F}$ to $119^{\circ} \mathrm{F}$ ) year-round, but sometimes temperature may fall at $34^{0} \mathrm{~F}$ during winter. The urban seasonal waterlogged areas are undeveloped residential wastelands that are under control of the cantonment board. These areas encompass the ditches and low laying grounds that receive water from domestic sewage and rainfall. 


\section{Birds Survey}

It has been known that avian populations fluctuate from time to time and habitat to habitats (Schieck, 1997; Blake and Loiselle, 2001). Determining the temporal changes is highly essential to understand the trends in avian population in the wetland areas (Thompson et al., 2002; DeSante et al., 2005). For this reason, the Distance Sampling Point Count Method is one of the most common quantitative survey technique that has been widely used to examine the temporal changes in avian populations (i.e. relative abundance, foraging guilds, and diversity) inhabiting different habitats (Verner and Purcell, 1999; Codesido and Bilenca, 2000). This method involves the visual and auditory detection of birds with fixed or variable radius plots, and it provides detailed information on avian population parameters (Verner and Ritter, 1985; Mills et al., 2000). The design of this study was encompassing of the following factors: (i) suitability for habitats, such as open water bodies and vegetated areas, i.e. submerged vegetation; (ii) suitability for surveying cryptic, shy, and skulking species; (iii) suitability for species-rich populations; (iv) suitability in situations where human access was restricted; and (v) areas best situated for bird-habitat studies.

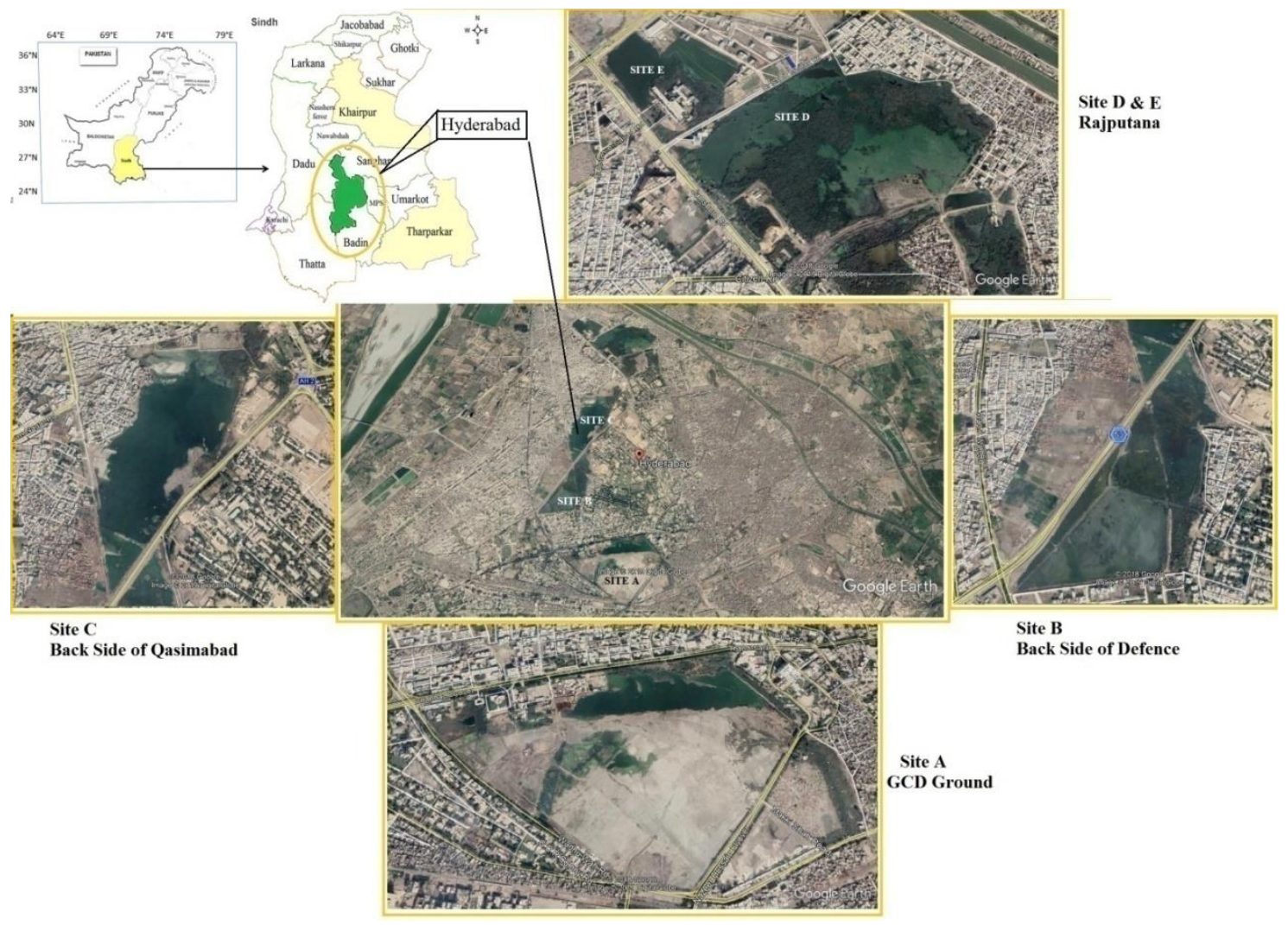

Figure 1. Location map of the study area

Avian species inventories at five selected sites were carried out from September 2014 to February 2015 and September 2018 to February 2019 employing Distance Sampling Point Count method. A total of 150 point count stations (i.e., in site 30 point count stations) were fixed at $300 \mathrm{~m}$ intervals along the edges of water bodies to avoid double counting the same bird individuals at more than one station (Meadows et al., 
2012; Wijesundara and Wijesundara, 2014; Adams et al., 2015). The birds were surveyed at each point count station for 15 minutes during each visit. The surveys were carried out during 0750-1100 hrs. This period of time is appropriate as most of the avian species remain active in search of food. The sampling methodology was followed as described by Richardson et al. (2001), Buckland et al. (2004), Aborn (2007), Nadeau et al. (2008), and Yu-Seong et al. (2008).

\section{Data Analysis}

Relative abundance revealed the common or rare species inhabiting in a particular area. It is the percentage composition of particular bird species among all detected bird species utilizing the waterlogged area (Simon and Okoth, 2016; Walag and Canencia, 2016; James and Bright, 2017). Relative abundance (\%) of avian species was determined to employ the following formula;

$$
\text { Relative Abundance }=\frac{\mathrm{n} i}{\mathrm{~N}} \times 100
$$

where, $\mathrm{n} i=$ is the number of individuals in the $i$ th bird species, $\mathrm{N}=$ is total detected numbers of individuals of species detected in urban seasonal waterlogged areas (Bibby et al., 2000; Hubbell, 2001; McGill et al., 2007).

Avian diversity was analyzed using the Community Analysis Package (PCA) Version 4.0 by Henderson and Seaby (2007). The reliability of data of tested through Shapiro-Wilk normality test (Analytical Software version 8.1) by Razali (2011).

The status of avian species was identified and confirmed with the help of IUCN RedList and BirdLife International checklist.

\section{Results}

\section{Relative Abundance}

The results of 2018/19 stated that urban waterlogged areas had attracted highest relative abundance (i.e., 28229 bird individuals equal to $61.793 \%$ ) representing 50 species and 14 families as compared to 2014/15 (i.e., 17454 bird individuals equal to $38.207 \%$ ) represent 38 species and 12 families. This indicated that $23.586 \%$ higher numbers of bird individuals were detected in 2018/19. Furthermore, twelve new avian species namely; Common Teal - Anas cerca, Green-winged Teal - Spatula discors, Mallard - Anas platyrhinchos, Gadwall - Meraca strepera, Great Cormorant Phalacrocorax carbo, Brown-headed Gull - Larus brunnicephalus, Black Kite Milvus migrans, Bar-tailed Godwit - Limosa lapponica, Spoon-billed Ibis - Platalea leucorodia, Pied Avocet - Recurvirostra avosetta, Solitary Sandpiper - Tringa solitaria, Spotted Sandpiper - Actitis macularius, and White-tailed Lapwing - Chettus ialeucura were detected in 2018/19 as compared to 2014/15 (Table 1).

In addition, the results obtained using the One-Way ANOVA and Tukey's HSD test showed that the avian relative abundance of the urban seasonal waterlogged area was significantly different in the $2018 / 19$ and $2014 / 15$ periods (i.e., $\mathrm{F}_{1}, 86=4.46, \mathrm{P}<0.05$; $\mathrm{CV}=2 / 81)$. 
Table 1. Ranking of waterbird species recorded in urban seasonal waterlogged areas

\begin{tabular}{|c|c|c|c|c|c|c|}
\hline Family & Common Name & Scientific name & $\begin{array}{c}\text { Detected } \\
\text { Observation } \\
\text { in 2014/15 }\end{array}$ & $\%$ & $\begin{array}{c}\text { Detected } \\
\text { Observation } \\
\text { in 2018/19 }\end{array}$ & $\%$ \\
\hline Anatidae & Northern Pintail & Anas acuta & 1490 & 3.262 & 1958 & 4.286 \\
\hline Anatidae & Common Teal & Anas cerca & 1870 & 4.093 & 1922 & 4.207 \\
\hline Anatidae & Green-winged Teal & Spatula discors & - & - & 1870 & 4.093 \\
\hline Anatidae & Mallard & Anas platyrhinchos & - & - & 1824 & 3.993 \\
\hline Anatidae & Gadwall & Meraca strepera & - & - & 1760 & 3.853 \\
\hline Anatidae & Baikal Teal & Sibirionetta formosa & 1260 & 2.758 & 1656 & 3.625 \\
\hline Anatidae & Northern Shoveler & Spatula clypeata & 1630 & 3.568 & 1558 & 3.410 \\
\hline Anatidae & Falcated Duck & Mareca falcate & 975 & 2.134 & 1234 & 2.701 \\
\hline Laridae & River Tern & Sterna aurantia & 486 & 1.064 & 860 & 1.883 \\
\hline Anatidae & Garganey & Spatula querquedula & 680 & 1.489 & 859 & 1.880 \\
\hline Scolopacidae & Black-winged Stilt & Himantopus himantopus & 660 & 1.445 & 752 & 1.646 \\
\hline Phalacrocoracidae & Indian Cormorant & Phalacrocorax fuscicollis & 610 & 1.335 & 752 & 1.646 \\
\hline Laridae & Common Tern & Sterna hirundo & 640 & 1.401 & 742 & 1.624 \\
\hline Phalacrocoracidae & Great Cormorant & Phalacrocorax carbo & - & - & 656 & 1.436 \\
\hline Laridae & Black-headed Gull & $\begin{array}{l}\text { Chroicocephalus } \\
\text { ridibundus }\end{array}$ & 240 & 0.525 & 639 & 1.399 \\
\hline Phalacrocoracidae & Little Cormorant & Micro carboniger & 780 & 1.707 & 576 & 1.261 \\
\hline Laridae & Brown-headed Gull & Larus brunnicephalus & - & - & 545 & 1.193 \\
\hline Charadriidae & Red-wattled Lapwing & Vanellus indicus & 130 & 0.284 & 537 & 1.175 \\
\hline Ardeidae & Little Egret & Egretta garzetta & 870 & 1.904 & 460 & 1.007 \\
\hline Laridae & Short-billed Gull & Larus brachyrhynchus & 235 & 0.514 & 458 & 1.003 \\
\hline Scolopiacidae & Little Stint & Calidris minuta & 830 & 1.817 & 447 & 0.978 \\
\hline Ardeidae & Cattle Egret & Bubulcus ibis & 567 & 1.241 & 439 & 0.961 \\
\hline Laridae & Short-tailed Gull & Larus canus & 340 & 0.744 & 434 & 0.950 \\
\hline Accipitridae & Black Kite & Milvus migrans & - & - & 430 & 0.941 \\
\hline Charadriidae & $\begin{array}{l}\text { Yellow-wattled } \\
\text { Lapwing }\end{array}$ & Vanellus malarbaricus & 40 & 0.088 & 388 & 0.849 \\
\hline Scolopacidae & Bar-tailed Godwit & Limosa lapponica & - & - & 376 & 0.823 \\
\hline Podicipedidae & Little Grebe & Tachybaptus ruficollis & 589 & 1.289 & 348 & 0.762 \\
\hline Ardeidae & Intermediate Egret & Egretta intermedia & 546 & 1.195 & 324 & 0.709 \\
\hline Ardeidae & Indian Pond Heron & Ardeol grayii & 100 & 0.219 & 290 & 0.635 \\
\hline Scolopacidae & Marsh Sandpiper & Tringa stagnatilis & 290 & 0.635 & 267 & 0.584 \\
\hline Motacillidae & Yellow Wagtail & Motacilla flava & 181 & 0.396 & 220 & 0.482 \\
\hline Scolopacidae & Common Sandpiper & Actis hypoleucos & 214 & 0.468 & 217 & 0.475 \\
\hline Motacillidae & White Wagtail & Motacilla alba & 150 & 0.328 & 198 & 0.433 \\
\hline Ardeidae & Great Egret & Casmerodius albus & 367 & 0.803 & 195 & 0.427 \\
\hline Scolopacidae & Terek Sandpiper & Xenus cinereus & 209 & 0.458 & 194 & 0.425 \\
\hline Threskiornithidae & Spoon-billed Ibis & Platalea leucorodia & - & - & 189 & 0.414 \\
\hline Phoenicopteridae & Greater Flamingo & Phoenicopterus roseus & 34 & 0.074 & 180 & 0.394 \\
\hline Recurvirostridae & Pied Avocet & Recurvirostra avosetta & - & - & 170 & 0.372 \\
\hline Scolopacidae & Wood Sandpiper & Tringa glareola & 50 & 0.109 & 168 & 0.368 \\
\hline Alcedinidae & Pied Kingfisher & Ceryle rudis & 20 & 0.044 & 160 & 0.350 \\
\hline Rallidae & Common Moorhen & Gallinula chlorpus & 40 & 0.088 & 155 & 0.339 \\
\hline Scolopacidae & Green Sandpiper & Tringa ochropus & 164 & 0.359 & 148 & 0.323 \\
\hline Scolopacidae & Solitary Sandpiper & Tringa solitaria & - & - & 134 & 0.293 \\
\hline Scolopacidae & Spotted Sandpiper & Actitis macularius & - & - & 130 & 0.285 \\
\hline Scolopacidae & Lesser Sand Plover & Charadrius mongolus & 27 & 0.059 & 124 & 0.271 \\
\hline Charadriidae & White-tailed Lapwing & Chettus ialeucura & - & - & 106 & 0.232 \\
\hline Scolopacidae & Grey Plover & Pluvialis squatarola & 18 & 0.039 & 64 & 0.140 \\
\hline Rallidae & $\begin{array}{l}\text { White-breasted } \\
\text { Waterhen }\end{array}$ & Amaurornis phoenicurus & 78 & 0.171 & 46 & 0.101 \\
\hline Alcedinidae & $\begin{array}{l}\text { White-throated } \\
\text { Kingfisher }\end{array}$ & Halcysmyrnensis & 30 & 0.066 & 45 & 0.099 \\
\hline \multirow{3}{*}{ Scolopacidae } & Sociable Lapwing & Vanellus gregarius & 14 & 0.031 & 25 & 0.055 \\
\hline & Total 39 Species & Total & 17454 & & 28229 & \\
\hline & & & & 45683 & & \\
\hline
\end{tabular}




\section{Relative Abundance of Migrant, Resident, Resident-Migrant Bird Species}

Notably, 18965 bird individuals of 30 migrant species representing 6 families were detected in 2018/19 as compared to 11547 bird individuals of 22 species and 5 families detected in 2014/15. Likewise, 5370 individuals of 15 resident species were detected in 2018/19 and 5247 individuals of 15 resident species in 2014/15. However, 5 residentmigrant bird species (i.e. 3897 individuals) were detected in 2018/19 while 660 bird individuals of Himantopus himantopus resident-migrant species (i.e.) were detected in 2014/15. Out of 30 migrant bird species, one species was critically endangered; two species $\mathrm{Ra} / \mathrm{A} / \mathrm{Vu}$ (Rare/Accidental/Vulnerable) and the rest 23 species were least concern based on IUCN Status. All resident bird species were totally protected and one resident-migrant bird species as data deficient (Table 2).

\section{Foraging Guilds Structure in the 2018/19 and 2014/15 Periods}

Notably, the findings of foraging guild structure 2018/19 stated that currently, urban seasonal waterlogged areas had attracted a higher number of bird individuals than previous years (i.e., guild omnivore; $32.489 \%$ in 2018/19 and $17.562 \%$ in 2014/15). Likewise, the higher relative abundance of guild Piscivore was detected in 2019 $(12.808 \%)$ rather than 2014/15 (7.292\%). On the contrarily, lower number of bird individuals of guild Carnivore/Piscivore/Insectivore were detected in 2019 (4.188\%) rather than 2014/15 (5.472\%). Moreover, the member of guild Carnivore was detected in 2018/19 but no individuals of Carnivore was documented in 2014/15 period (Table 3).

\section{Comparison of Diversity Indices}

The results of the alpha diversity analysis indicated that urban seasonal waterlogged areas had attracted higher diversity of avian species in 2018/19 rather than 2014/15 (Table 4).

\section{Discussions}

The urban seasonal waterlogged areas investigated in this study encompasses of $30.0 \%$ rush and sedge aquatic plants while rest is shallow water open areas devoid of aquatic vegetation. Rush and sedge plants serve as hiding cover for avian species while open water areas as foraging grounds. The shallow water is rich in food resources, such as fishes, amphibians, insects, crustaceans and aquatic plants which is the major diet of avian species especially waterfowl, seagulls, cormorant, grebes, plovers, sandpipers, stilt, and egrets.

Urban seasonal waterlogged areas are a highly important habitat for a wide array of waterbirds and terrestrial birds. Their importance depends on many factors, namely; size, connectivity to surrounding areas, diversity of vegetation, water quality, occurrence of food resources and disturbance. Besides, determining the temporal changes in avian population parameters is highly important to obtain the population trend of different avian species utilizing these areas. Evidently, the results of the diversity analysis in the study indicated that the bird diversity during consequent time period might vary depending on the habitat suitability, richness of food resources, and feeding guilds in the wetland reserve. 
Table 2. List of migrant, resident, and resident-migrant bird species detected in urban seasonal waterlogged areas of Hyderabad, Sindh Pakistan in the 2014/15 and 2018/19 periods

\begin{tabular}{|c|c|c|c|c|c|c|c|}
\hline Family & Common Name & Scientific Name & Current Status & $\begin{array}{c}\text { Detected Observation in } \\
2014 / 15\end{array}$ & $\%$ & $\begin{array}{c}\text { Detected Observation } \\
\text { in } 2018 / 19\end{array}$ & $\%$ \\
\hline \multicolumn{8}{|c|}{ Migrant Bird Species } \\
\hline Anatidae & Northern Pintail & Anas acuta & $\mathrm{LC}$ & 1490 & 4.883 & 1958 & 6.417 \\
\hline Anatidae & Common Teal & Anas cerca & $\mathrm{LC}$ & 1870 & 6.192 & 1922 & 6.299 \\
\hline Anatidae & Mallard & Anas platyrhinchos & $\mathrm{LC}$ & - & - & 1824 & 5.978 \\
\hline Anatidae & Gadwall & Meraca strepera & $\mathrm{LC}$ & - & - & 1760 & 5.768 \\
\hline Anatidae & Baikal Teal & Sibirionetta formosa & $\mathrm{Ra} / \mathrm{A} / \mathrm{Vu}$ & 1260 & 4.130 & 1656 & 5.427 \\
\hline Anatidae & Northern Shoveler & Spatula clypeata & LC & 1630 & 5.342 & 1558 & 5.106 \\
\hline Anatidae & Falcated Duck & Mareca falcate & $\mathrm{Ra} / \mathrm{A} / \mathrm{Vu}$ & 975 & 3.195 & 1234 & 4.044 \\
\hline Anatidae & Garganey & Spatula querquedula & LC & 680 & 2.229 & 859 & 2.815 \\
\hline Laridae & Common Tern & Sterna hirundo & $\mathrm{LC}$ & 640 & 2.098 & 742 & 2.432 \\
\hline Laridae & Black-headed Gull & Chroicocephalus ridibundus & $\mathrm{LC}$ & 240 & 0.787 & 639 & 2.094 \\
\hline Laridae & Brown-headed Gull & Larus brunnicephalus & $\mathrm{LC}$ & - & - & 545 & 1.786 \\
\hline Laridae & Short-billed Gull & Larus brachyrhynchus & $\mathrm{LC}$ & 235 & 0.770 & 458 & 1.501 \\
\hline Scolopiacidae & Little Stint & Calidris minuta & $\mathrm{LC}$ & 830 & 2.720 & 447 & 1.465 \\
\hline Laridae & Short-tailed Gull & Larus canus & $\mathrm{LC}$ & 340 & 1.114 & 434 & 1.422 \\
\hline Charadriidae & Yellow-wattled Lapwing & Vanellus malarbaricus & $\mathrm{LC}$ & 40 & 0.132 & 388 & 1.272 \\
\hline Scolopacidae & Bar-tailed Godwit & Limosa lapponica & $\mathrm{LC}$ & - & - & 376 & 1.232 \\
\hline Scolopacidae & Marsh Sandpiper & Tringa stagnatilis & $\mathrm{LC}$ & 290 & 0.950 & 267 & 0.875 \\
\hline Motacillidae & Yellow Wagtail & Motacilla flava & $\mathrm{LC}$ & 181 & 0.593 & 220 & 0.721 \\
\hline Scolopacidae & Common Sandpiper & Actis hypoleucos & $\mathrm{LC}$ & 214 & 0.701 & 217 & 0.711 \\
\hline Motacillidae & White Wagtail & Motacilla alba & $\mathrm{LC}$ & 150 & 0.492 & 198 & 0.649 \\
\hline Scolopacidae & Terek Sandpiper & Xenus cinereus & $\mathrm{LC}$ & 209 & 0.685 & 194 & 0.636 \\
\hline Recurvirostridae & Pied Avocet & Recurvirostra avosetta & $\mathrm{LC}$ & - & - & 170 & 0.557 \\
\hline Scolopacidae & Wood Sandpiper & Tringa glareola & $\mathrm{LC}$ & 50 & 0.164 & 168 & 0.551 \\
\hline Scolopacidae & Green Sandpiper & Tringa ochropus & $\mathrm{LC}$ & 164 & 0.537 & 148 & 0.485 \\
\hline Scolopacidae & Solitary Sandpiper & Tringa solitaria & $\mathrm{LC}$ & - & - & 134 & 0.439 \\
\hline Scolopacidae & Spotted Sandpiper & Actitis macularius & $\mathrm{LC}$ & - & - & 130 & 0.426 \\
\hline Scolopacidae & Lesser Sand Plover & Charadrius mongolus & $\mathrm{LC}$ & 27 & 0.088 & 124 & 0.406 \\
\hline Charadriidae & White-tailed Lapwing & Vanellus leucurus & $\mathrm{LC}$ & - & - & 106 & 0.347 \\
\hline Scolopacidae & Greater Sand Plover & Charadrius leschenaultii & $\mathrm{LC}$ & 18 & 0.059 & 64 & 0.210 \\
\hline Scolopacidae & Sociable Lapwing & Vanellus gregarious & $\mathrm{CE}$ & 14 & 0.046 & 25 & 0.082 \\
\hline \multicolumn{4}{|c|}{ Sub-Total } & 11547 & & 18965 & \\
\hline & & & & & 30512 & & \\
\hline
\end{tabular}




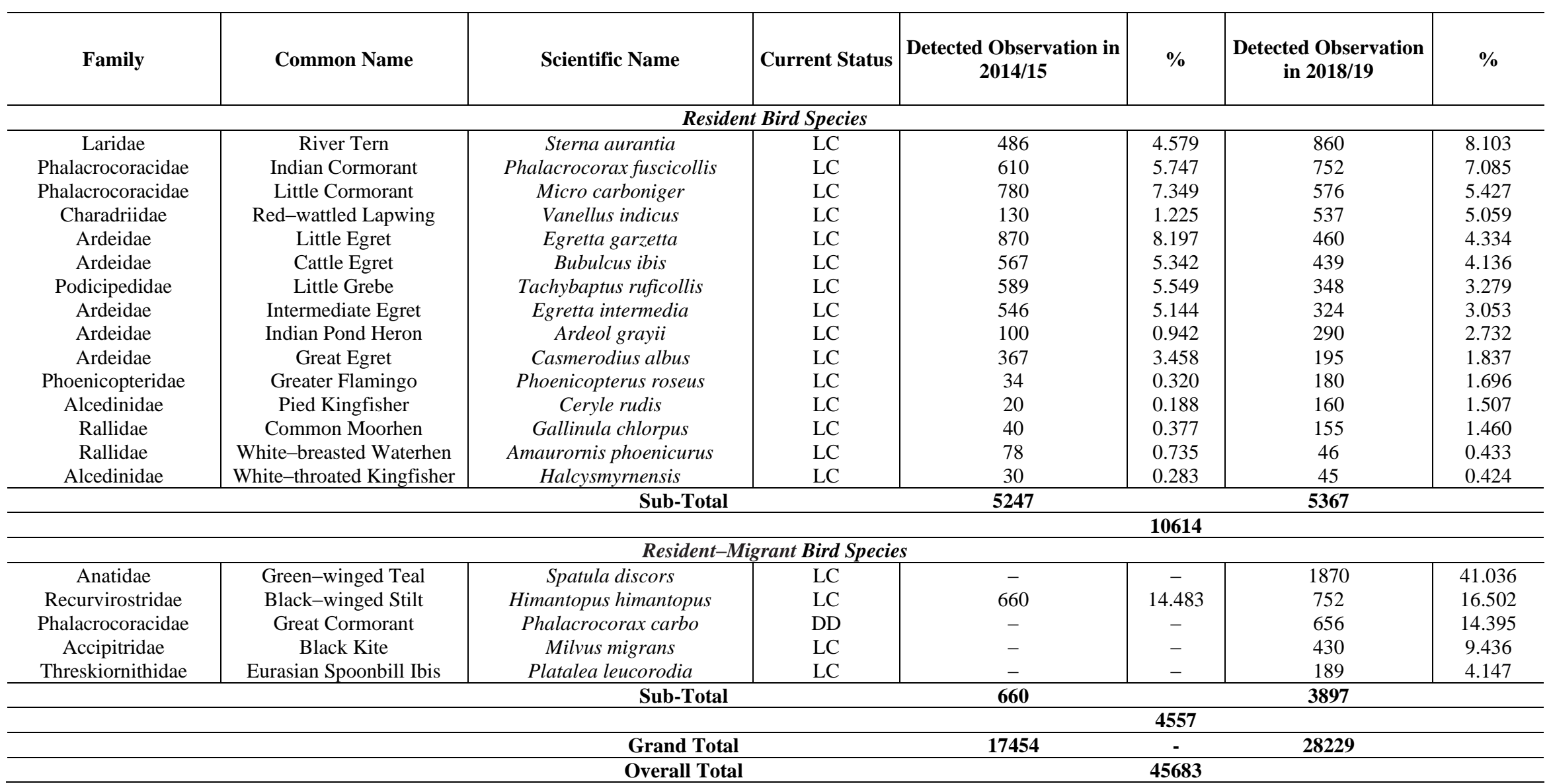

(LC = Least Concern, $\mathrm{Ra}=$ Rare, $\mathrm{A}=$ Accidental, $\mathrm{Vu}=$ Vulnerable, $\mathrm{CE}=$ Critically Endangered, $\mathrm{DD}=\mathrm{Data}$ Deficient $, \mathrm{M}=\mathrm{Migrant}, \mathrm{Re}=\mathrm{Resident}$, and $\mathrm{R}-\mathrm{M}=$ Resident-Migrant) 
Table 3. List of foraging guild based on the number of species and the total number of detections

\begin{tabular}{c|c|c|c|c}
\hline \multirow{2}{*}{ Guild Name } & \multicolumn{2}{|c|}{ Year 2014/15 } & \multicolumn{2}{c}{ Year 2018/19 } \\
\cline { 2 - 5 } & Observations & Percentage & Observations & Percentage \\
\hline Omnivore & 8023 & 17.562 & 14842 & 32.489 \\
Piscivore & 3331 & 7.292 & 5851 & 12.808 \\
Piscivore/Insectivore & 3235 & 7.081 & 4595 & 10.058 \\
Carnivore/Piscivore/Insectivore & 2500 & 5.472 & 1913 & 4.188 \\
Insectivore & 331 & 0.725 & 418 & 0.915 \\
Detritivore & 34 & 0.074 & 180 & 0.394 \\
Carnivore & - & - & 430 & 0.941 \\
\hline Sub-Total & $\mathbf{1 7 4 5 4}$ & \multicolumn{3}{|c}{$\mathbf{4 5 6 8 3}$} \\
\hline Grand Total & \multicolumn{3}{|c}{} \\
\hline
\end{tabular}

Table 4. Comparison of diversity indices of avian species inhabiting urban seasonally waterlogged areas in the 2018/19 and 2014/15 periods

\begin{tabular}{|c|c|c|c|c|c|c|c|c|}
\hline \multirow[b]{2}{*}{ Indices } & \multicolumn{4}{|c|}{ 2018/19 } & \multicolumn{4}{|c|}{$2014 / 15$} \\
\hline & Overall & Migrant & Resident & $\begin{array}{c}\text { Resident- } \\
\text { Migrant }\end{array}$ & Overall & Migrant & Resident & $\begin{array}{c}\text { Resident- } \\
\text { Migrant }\end{array}$ \\
\hline \multicolumn{9}{|l|}{ Shannon's Index } \\
\hline $\mathrm{H}$ & 17.48 & 11.38 & 7.399 & 2.232 & 8.04 & 4.866 & 3.036 & 0.502 \\
\hline Exp. H & 82.6 & 48.47 & 27.43 & 4.762 & 55.54 & 31.21 & 20.96 & 4.527 \\
\hline Lower H@95\% & 12.2 & 7.737 & 4.757 & 0.558 & 8,04 & 4.866 & 3.038 & 0.562 \\
\hline Upper H@99\% & 14.84 & 10.01 & 6.342 & 2.232 & 8.04 & 4.866 & 3.036 & 0.502 \\
\hline \multicolumn{9}{|l|}{ Margalef's Index } \\
\hline $\mathrm{R}_{1}$ & 4.414 & 3.881 & 3.312 & 1.561 & 4.017 & 3.441 & 3.043 & 1.51 \\
\hline Lower H@95\% & 3.943 & 3.393 & 2.741 & 0.637 & 4.008 & 3.43 & 3.029 & 1.495 \\
\hline Upper H @ 99\% & 4.181 & 3.677 & 3.128 & 1.561 & 4.026 & 3.453 & 3.054 & 1.527 \\
\hline \multicolumn{9}{|l|}{ McIntosh's Index } \\
\hline $\mathrm{E}$ & 0.971 & 0.960 & 0.947 & 0.893 & 0.851 & 0.802 & 0.773 & 0.525 \\
\hline Lower H@95\% & 0.929 & 0.902 & 0.853 & 0.430 & 0.850 & 0.801 & 0.771 & 0.520 \\
\hline Upper H@99\% & 0.950 & 0.937 & 0.918 & 0.893 & 0.852 & 0.804 & 0.774 & 0.532 \\
\hline
\end{tabular}

Evidently, the results of population parameters are noteworthy, in comparisons; the higher relative abundance, bird species, foraging guilds, and diversity indices were detected in the 2018/19 rather than $2014 / 15$ period. This indicate that urban seasonal waterlogged areas has becomes more attractive habitat with the passage of time for avian species as compared to previous years. The recording of higher relative abundance, species composition, foraging guilds, and diversity indices could be that these areas are less disturbed even though they are located within the heart of the city. Because nobody hunting in these areas due to under administration of cantonment board. The other reason might be that these areas are rich in fish fingerlings, amphibians, insect larvae, and organic matter. These food resources are the major diet of waterbird as well as terrestrial bird species. The third reason could be that natural wetland areas of the Hyderabad have lost due to conversion into agriculture fields, water pollution, and aquaculture ponds, and urban settlements. Due to these reasons, urban seasonal waterlogged areas of the Hyderabad serve as an alternate habitat for a wide array of waterbird as well as terrestrial bird species, especially in winter.

Furthermore, it was observed that the relative abundance of waterbird was influenced by vegetation structure, food resources, and water level that affected the habitat selection. This could be that these factors indicated where and how the waterbirds used the urban waterlogged areas. For example; waterfowl, grebes and cormorant often 
utilized open water areas devoid of aquatic vegetation for foraging (waterfowls, sandpipers, lapwings, stilts, cormorants, terns, and egrets) and dead fallen trees for perching (cormorants and egrets). Likewise, egrets, herons, sandpipers, plovers, and lapwings selected shallow waters for foraging and substrate for perching and avoided the deep waters. This could be that deep water may restrict their prey accessibility and reduced the prey-capturing success (Gawlik, 2002; Brönmark and Hansson, 2005).

Additionally, it was also observed that the richness and diversity of food resources may regulate the distribution and diversity of waterbird species in aquatic habitat (Johnson and Sherry, 2001; Sutula and Stein, 2003). Furthermore, this study highlighted that waterbird species are habitat specialist, they often selected habitat that offers ideal foraging and perching sites, shelter from predator and harsh weather. Relatively, water depth, vegetation structure and composition, richness and diversity of food resources, and dead fallen trees in urban waterlogged areas play a significant role in foraging guild structure (Kiviat and MacDonald, 2004; Benassi et al., 2007; Guadagnin et al., 2009; Tsai et al., 2012).

Conversely, seven foraging guilds were recorded in 2018/19 and six foraging guilds in 2014/15 period. Apparently, the recording of seven feeding guilds of the avian species in urban waterlogged areas in the 2018/19 showed that this seasonal fragile habitat provided suitable food and foraging sites for a wide array of avian species (i.e., waterbirds and terrestrial birds). Furthermore, the results of foraging guild structure revealed that urban seasonal waterlogged areas are rich in food diversity, vegetation structure, and water level that may play a crucial role to attract a higher diversity of avian species especially waterbirds. It was observed that piscivore, i.e., cormorant, egrets, heron, and kingfishers preyed on fishes especially in shallow waters, omnivore i.e., waterfowls foraged on animal (fishes, amphibians, invertebrates, etc.) and plant matter (aquatic plants) that floating at the surface of the water or occurs in shallow waters, insectivore, i.e., stilt, sandpipers, and lapwing, etc mostly preferred shallow water and soft mud to prey on aquatic invertebrates (Guadagnin et al., 2009).

Furthermore, the results foraging behavior also indicated that the waterbirds and terrestrial birds inhabiting in urban waterlogged areas were highly variable in their morphological structures, foraging behavior, and food capturing tactics, and habitat selections. The members of each foraging guild varied in their food selection due to morphological differences, bill and tarsus size, water depth and habitat preferences.

\section{Conclusions}

The findings of this study indicated that urban seasonal waterlogged area is suitable habitat (foraging sites and stopover) for a wide array of waterbird species especially migrant birds to refuel, rest, and forage. Unfortunately, these fragile areas have been shrinking at an alarm rate due to urban development. For conservationist, dealing with the human and maintaining the functional waterlogged ecosystem is the greatest challenge to conserve and protect these fragile aquatic habitats. The existence, sustainability, and future of avian species directly depend on protection and conservation of the urban waterlogged areas of Hyderabad and across the country. Hence, it is strongly recommended that the urban seasonal waterlogged areas should be declared as wetland reserve (wetland of global importance) due to harboring a variety of migrants as well as native waterbird species that belong to different taxonomic groups. 


\section{REFERENCES}

[1] Aborn, D. A. (2007): Abundance, Density and Diversity of Neotropical Migrants at the Lula Lake Land Trust, GA. - Southeastern Naturalist 6(2): 293-304.

[2] Adams, H. L., Wes Burger, J. L., Riffel, S. (2015): Edge effects on avian diversity and density of native grass conservation buffers. - The Open Ornit. J. 8: 1-9.

[3] Benassi, G., Battisti, C., Luiselli, L. (2007): Area effect on bird species richness of an arcipelago of wetland fragments of Central Italy. - Comm. Ecol. 8: 229-237.

[4] Bibby, C. J., Burgess, N. D., Hill, D. A., Mustoe, S. (2000): Bird Census Techniques. London; Academic Press, UK. Second Edition. Pp. 91-112.

[5] BirdLife International (2015): Migratory Birds and Flyways. - URL: http://www.birdlife.org/worldwide/ programme-additional-info/migratory-birds-andflyways.

[6] Blake, J. G., Loiselle, B. A. (2000): Diversity of birds along an elevational gradient in the Cordillera Central, Costa Rica. - Auk 117: 663-686.

[7] Brönmark, C., Hansson, L.-A. (2005): The Biology of Lakes and Ponds. - Oxford University Press, Oxford, New York. Second Edition. Pp. 285.

[8] Buckland, S. T., Anderson, D. R., Burnhan, K. P., Lake, J. L., Borchers, D. L., Thomas, L. (2004): Advance Distance Sampling; Estimating Abundance of Biological Populations. - London; Campman and Hall. Pp. 141-172. ISBN: 0-19-850927-8.

[9] Catford, J. A., Walsh, C. J., Beadall, J. (2007): Catchment urbanization increases benthic micro algal biomass in streams under control light conditions. - Aquatic Science 69: 511522.

[10] Codesido, M., Bilenca, D. N. (2000): Comparacion de los metodos de transecta de fajay de conteo de puntos de radio fijo en una comunidad de aves del bosque semiárido santiagueño. - El Hornero 15: 85-91.

[11] Davis, J., Sim, L., Chambers, J. (2010): Multiple stressors and regime shifts in shallow aquatic ecosystems in antipodean landscapes. - Freshwater Biology 55: 5-18.

[12] DeSante, D. F., Nott, M. P., Kaschube, D. R. (2005): Monitoring, modelling, and management: why base avian monitoring on vital rates and how should it be done. - In: Ralph, C. J., Rich, T. D. (eds.) Bird conservation implementation and integration in the Americas. U.S. Forest Service General Technical Report PSW-GTR-191. Albany, California, USA. Pp. 795-804.

[13] Ehrenfed, J. (2000): Evaluating wetlands within an urban context. - Ecological Engineering 15: 253-265.

[14] Fraser, L. H., Keddy, P. A. (2005): The World's Largest Wetlands: Ecology and Conservation. - Cambridge University Press, U.K.

[15] Gawlik, D. E. (2002): The effect of prey availability on the numerical response of wading birds. - Ecological Monographs 72: 329-346.

[16] Gibbs, J. P., Whiteleather, K. K., Schueler, F. W. (2005): Changes in frog and toad populations over 30 years in New york State. - Ecological Applications 15: 1148-1157.

[17] Guadagnin, D. L., Maltchik, L., Fonseca, C. R. (2009): Species-area relationship of Neotropical waterbird assemblages in remnant wetlands. - Diversity and Distributions 15 : 319-327.

[18] Henderson, P. A., Seaby, R. M. H. (2007): Community Analysis Package 4.0. - Pisces Conservation Ltd, Lymington, UK.

[19] Hoffmann, M. D., Dodson, S. I. (2005): Land use, primary productivity and lake area as desciptors of zooplankton diversity. - Ecology 86: 255-261.

[20] Hubbell, S. P. (2001): The unified neutral theory of biodiversity and biogeography. Princeton University Press, Princeton, N.J.

[21] James, A.-O., Emmanue, D., Bright, A. Y. (2017): Diversity and abundance of bird species in Mole National Park, Damongo, Ghana. - Journal of Natural Sciences Research 17(12): 20-33. 
[22] Johnson, M. D., Sherry, T. W. (2001): Effects of food availability on the distribution of migratory warblers among habitats in Jamaica. - Journal of Animal Ecology 70: 546-560.

[23] Kiviat, E., MacDonald, K. (2004): Biodiversity pattern and conservation in the Hacensack Meadowlands, New Jersey. - Urban Habitats 2(1): 28-61.

[24] Mackintosh, T., Davis, J. (2013): The Importance of Urban Wetlands. - In: Paul, S. (ed.) Workbook for Managing Urban Wetlands in Australia. Sydney Olympic Park Authority. URL: $\quad$ https://www.sopa.nsw.gov.au/Resource-Centre/WET-eBook-Workbook-forManaging-Urban-Wetlands-in-Australia\#. First Edition, ISNB: 978-0-9874020-0-4.

[25] McGill, B. J., Etienne, R. S., Gray, J. S., Alonso, D., Anderson, M. J., Benecha, H. K., Dornelas, M., Enquist, B. J., Green, J. L., He, F., Hulbert, A. H., Magurran, A. E., Marquet, P. A., Maurer, B. A., Ostling, A., Soykan, C. U., Ugland, K. L., White, E. P. (2007): Species abundance of bird distributions: moving beyond single prediction theories to integration within an ecological framework. - Ecology Letters 10: 995-1015.

[26] Meadows, S., Moller, H., Weller, F. (2012): Reduction of bias when estimating bird abundance within small habitat fragments. - New Zeal. J. Ecol. 36(3): 1-8.

[27] Mills, T. R., Rumble, M. A., Flake, L. D. (2000): Habitats of birds in ponderosa pine and aspen/birch forest in the Black Hills, South Dakota. - Journal of Field Ornithology 71: 187-206.

[28] Nadeau, C. P., Conway, C. J., Smith, B. S., Lewis, T. E. (2008): Maximizing detection probability of wetland dependent bird during point count surveys in North-western Florida. - The Wilson Journal of Ornithology 120(3): 513-518.

[29] Razali, N. M. (2011): Power comparisons of Shapiro-Wilk, Kolmogorov-Smirnov, Lilliefors and Anderson-Darling test. - Journal of Statistical Modeling and Analytics 2(1): 21-33.

[30] Richardson, A. J., Taylor, I. R., Growns, J. E. (2001): The foraging ecology of egrets in rice fields in southern New South Whales, Australia. - Waterbirds 24(2): 255-264.

[31] Schieck, J. (1997): Biased detection of bird vocalizations affects comparisons of bird abundance among forested habitats. - Condor 99: 179-190.

[32] Simon, G. S., Okoth, E. O. (2016): Species richness and abundance of birds in and around Nimule National Park, South Sudan. - Sci. Lett. 4(1): 92-94.

[33] Sutula, M., Stein, E. (2003): Habitat value of natural and constructed wetlands used to treat urban runoff: a literature review. - Southern California Coastal Water Research Project. Technical Report No. 388.

[34] Thompson III, F. R., Burhans, D. E., Root, B. (2002): Effects of point count protocol on bird abundance and variability estimates and power to detect population trends. - Journal of Field Ornithology 73(2): 141-150.

[35] Tsai, J-S., Venne, L. S., Smith, L. M., McMurry, S. T., Haukos, D. A. (2012). Influence of local and landscape characteristics of avian richness and density in wet Playas of the southern great plains, USA. - Wetland 32: 605-618.

[36] van der Walk, A. G. (2006): The Biology of Freshwater Wetlands. - Oxford University Press, Oxford. ISBN-10: 9780198525400.

[37] Vermoden, K., Leuven, R., Van der Velde, G., Van Katwijk, M. M., Roelofs, J. G. M. (2007): Urban drainage systems: An undervalued habitat for aquatic macro invertebrates. - Biological Conservation 142: 1105-1115.

[38] Verner, J., Ritter, L. V. (1985): A comparison of transects and point counts in oak-pine woodlands of California. - Condor 87: 47-68.

[39] Verner, J., Purcell, K. L. (1999): Fluctuating populations of House Wrens and Bewick's Wrens in foothills of the western Sierra Nevada of California. - Condor 101: 219-229.

[40] Walag, A. M. P., Canencia, M. O. P. (2016): Physio-chemical parameters and macrobenthic invertebrates of intertidal zone of Gusa, Cagayan de Oro City, Philippine. AES Bioflux 8(1): 71-82. 
[41] Wijesundara, C., Wijesundara, M. (2014): Bird Diversity of Dekinda Forest Reserve, Balana, Sri Lanka: Implications for Conservation. - Ceylon J. of Sci. (Bio. Sci.) 43(1): 137-146.

[42] Yu-Seong, C., Kwon, I., Yoo, J. (2008): A study of feeding methods in five species of heron and egrets in Korea. - Journal of Field Biology 31(2): 147-151.

[43] Zhang, M., Lei, G., Lu, C. (2010): Wetland conservation in China: Status, Challenges and Strategies. - Wetland Science and Practice 27(2): 16-23. 